\begin{tabular}{lcr}
\hline & ANNALES & \\
& & \\
UNIVERSITATIS MARIAE CURIE-SKLODOWSKA & \\
LOL. II & SECTIO M & 2017 \\
\hline
\end{tabular}

Wojciech Sokót

Uniwersytet Marii Curie-Skłodowskiej

\title{
Polityka reform systemów wyborczych do Zgromadzenia Narodowego w Bułgarii w latach 1990-2016
}

\section{Mieszany system wyborczy w Bułgarii jako rezultat rozmów Okrągłego Stołu}

W procesie demokratyzacji systemów politycznych istotną rolę odgrywają rywalizacyjne wybory parlamentarne i tym samym systemy wyborcze. Celem poniższego artykułu jest przedstawienie ewolucji systemów wyborczych do parlamentu Bułgarii, uwarunkowań polityki reform wyborczych, $w$ tym preferencji podmiotów politycznych uczestniczących w tym procesie. Kluczową kwestią jest także odpowiedź na pytanie: na ile przyjmowane w tym państwie w ciągu ostatnich ponad 25 lat rozwiązania wyborcze były adekwatne do przyjętych demokratycznych standardów w tej mierze.

W drugiej połowie lat osiemdziesiątych bułgarskie przywództwo komunistyczne stanęło pod znaczną presją ze strony Michaiła Gorbaczowa, aby rozpocząć reformy na wzór radzieckiej pierestrojki. Pierwsze kroki na rzecz ograniczonego współzawodnictwa wyborczego na poziomie zarówno lokalnym, jak i parlamentarnym podjęto w 1987 roku. Testem rywalizacji kilku kandydatów o jeden mandat były wybory do władz lokalnych w roku następnym ${ }^{1}$. Jak się okazało, konkurencyjna natura tych wyborów była ograniczona przez, wprawdzie

1 Zob. szerzej: J.D. Bell, Democratization and Political Participation in Post-Comminist Bulgaria, [w:] Politics, Power and the Struggle for Democracy in South - East Europe, red. K. Dawisha, B. Parrott, Cambridge University Press, Baltimore 1997, s. 354. 
bardziej zawoalowane, ale jednak dążenie ze strony Bułgarskiej Partii Komunistycznej (BKP) do kontrolowania procesu wyborczego ${ }^{2}$.

Przekonani o konieczności i nieuchronności zmian systemowych politycy partii komunistycznej ostatecznie 10 listopada 1989 roku odsunęli od steru rządów swego wieloletniego przywódcę Todora Żiwkowa i zainicjowali proces demokratycznych reform ${ }^{3}$. Zachęcone tymi odgórnymi impulsami wyłoniły się wkrótce opozycyjne wobec układu rządzącego grupy dysydentów, które od grudnia 1989 roku zaczęły działać pod nazwą Unia Demokratycznych Sił (SDS). Obydwie strony, zainteresowane powtórzeniem dobrze już wówczas znanego, polskiego, czeskiego czy węgierskiego modelu przemian, rozpoczęły negocjacje przy Okrągłym Stole. Rozmowy odbyły się między styczniem a majem 1990 roku. Przedmiotem debat były problemy reformy systemu politycznego, włącznie z ustaleniem warunków, według których miały być przeprowadzone pierwsze, tranzycyjne wybory ${ }^{4}$.

Reformy systemowe w Bułgarii były przykładem zmiany kontrolowanej, ponieważ Bułgarska Partia Komunistyczna była ich inicjatorem i determinowała w największym stopniu ich charakter łącznie z pierwszymi rywalizacyjnymi wyborami ${ }^{5}$. Składało się na to wiele przyczyn.

Po pierwsze, opozycja w listopadzie 1989 była słabo zinstytucjonalizowana - zwłaszcza na poziomie organizacyjnym (nieliczne członkostwo, brak kadr i infrastruktury materialnej) ${ }^{6}$. W porównaniu ze środowiskami komunistycznymi liderzy opozycji nie dysponowali kwalifikacjami (w tym między innymi umiejętnościami organizacyjnymi oraz powiązania strategii wyborczych z elementami systemów wyborczych) umożliwiającymi im skuteczną rywalizację na arenie wyborczej.

2 S. Ashley, Bulgaria, "Electoral Studies", 1990, vol. 9, nr 4, s. 312-318; J.D. Bell, Bulgaria, [w:] Developments in East European Politics, red. S. White, J. Batt, P. Lewis, Plograve, Basingstoke, 1993, s. 83-97.

${ }_{3}$ M. Żmigrodzki, Przeobrażenia polityczno-ustrojowe i Sad Konstytucyjny w Bułgarii, Wydawnictwo UMCS, Lublin 1997, s. 7-8.

4 Zob. szerzej: R. Nikolaew, Political Maneuvering Before the Round-table Talks, "Report on Eastern Europe", 1990, vol. 1, s. 5-7; V. Gawrilow, Communist Party and Opposition Sign Key Political Agreements, "Report on Eastern Europe", 1990, vol. 1, s. 1-4; A.P. Melone, Bulgaria's National Roundtable Talks and the Politics of Accomodation: Creating Parliamentary Government: The Transition to Democracy in Democracy in Bulgaria, red. A.P. Melone, Columbus 1998; R. Kolarowa, D. Dimitrow, The Roundtable Talks in Bulgaria, [w:] The Roundtable Talks and the Breakdown of Communism, red. J. Elster, University of Chicago Press, Chicago-London 1996, s. $178-212$.

5 Zob. szerzej: J. Wojnicki, Trudna droga do demokracji. Europa Środkowo-Wschodnia po 1989 roku, Wydawnictwo Autorskie, Warszawa 2002, s. 41-45.

6 A. Biagini, F. Guida, Pót wieku realnego socjalizmu: Europa Środkowowschodnia od II wojny światowej do upadku rządów komunistycznych, Wydawnictwo Wyższej Szkoły Pedagogicznej, Rzeszów 1998, s. 172-177. 
Po drugie, w przeciwieństwie do innych państw byłego bloku radzieckiego, gdzie komuniści znajdowali się wyraźnie w defensywie i próbowali w okresie przejściowym utrzymać tyle władzy, ile to tylko było możliwe, BKP w tym czasie była stroną dominującą w procesie negocjacji zmierzających do zmiany systemu. BKP prowadziła wstępne rokowania z opozycją już w grudniu 1989 roku, zanim rozpoczęły się oficjalne rozmowy Okrągłego Stołu. Przez pierwsze osiem miesięcy 1990 roku - zarówno przed, jak i po wyborach czerwcowych - ekskomuniści próbowali bezskutecznie nakłonić działaczy SDS do tego, aby weszli w skład rządu koalicyjnego. Niewątpliwie takie zachowania o charakterze konsensualnym stwarzały możliwości uzyskania zamierzonych celów w procesie negocjacji oraz były elementem szerokiej formuły legitymizacyjnej elit postkomunistycznych w nowych uwarunkowaniach systemowych.

Rozmowy Okrągłego Stołu w Bułgarii od strony instytucjonalnej odwoływały się do doświadczeń między innymi polskich czy węgierskich; posiadały formę zarówno obrad plenarnych, transmitowanych przez radio i (w skróconej wersji) przez telewizję, jak i formę "grup roboczych” o charakterze zamkniętym Głównymi podmiotami negocjacji byli dawni działacze partii komunistycznej oraz SDS ${ }^{8}$. Negocjacje na temat wyborów toczyły się wokół pięciu kluczowych kwestii: (1) czasu wyborów - BKP/Bułgarska Partia Socjalistyczna (BSP) postulowała przeprowadzenie wyborów nie później niż w czerwcu 1990 roku, SDS zaś, licząc na zmobilizowanie swojego potencjalnego elektoratu, była zainteresowana przesunięciem tego wydarzenia o kilka miesięcy później (wrzesień 1990 roku). Dążąc do realizacji swojej propozycji i chcąc grać na zwłokę, SDS mogła zagrozić zerwaniem negocjacji'; (2) rozmiaru i charakteru instytucji parlamentarnej, która miała być wybrana: BSP opowiadała się za wyborami parlamentarnymi do 200-250 mandatowej izby, a SDS, nawiązując do rozwiązań tyrnowskich, postulowała wybranie Wielkiego Zgromadzenia Narodowego; (3) sposobu wyłaniania prezydenta: wybieranego $\mathrm{w}$ wyborach powszechnych i bezpośrednich, za czym opowiadała się BKP/BSP, biorąc pod uwagę popularność ich lidera Petera Mładenowa, lub wybieranego w inny sposób, za czym opowiadała się SDS;

7 M. Orlikowski, Siadają do stołu, „Gazeta Wyborcza”, 3 I 1990; Magdalenka po butgarsku, „Gazeta Wyborcza”, 31 III-1 IV 1990.

8 Na nadzwyczajnym kongresie BKP odbywającym się w styczniu-lutym 1990 (w czasie rozmów) uzgodniono usunięcie konstytucjonalnego zapisu gwarantującego im kierowniczą rolę w państwie, jak i zmieniono nazwę na Bułgarską Partię Socjalistyczną; E. Centkowska, Jesień Ludów'89. Kalendarium wydarzeń, Wydawnictwa Szkolne i Pedagogiczne, Warszawa 1992, s. 94-96; J. Gorzkowski, W. Morawski, Jesień narodów, Oficyna Wydawnicza Volumen, Warszawa 1991, s. 102-105.

9 R. Kolarowa, D. Dimitrow, op. cit., s. 190. 
(4) statusu partii politycznych i procedur ich rejestracji; (5) systemu wyborczego: BKP/BSP początkowo proponowała system mieszany równoległy, w którym 175 przedstawicieli byłoby wybieranych według obecnej formuły większościowej, natomiast $75 \mathrm{w}$ konsekwencji formuły proporcjonalnej.

Rozpatrywanie pięciu wymienionych kwestii w ramach jednego pakietu reform politycznych stworzyło podstawy do wypracowania kompromisu. Strona demokratyczna wyraziła zgodę na wcześniejsze wybory w zamian za wybór prezydenta przez legislaturę (w tym przypadku przez Wielkie Zgromadzenie Narodowe). Istotny kompromis dotyczył również rozwiązań wyborczych; SDS wyraziła zgodę na wariant systemu mieszanego zaproponowany przez BSP w zamian za zwołanie Wielkiego Zgromadzenia Narodowego zamiast „zwyczajnego” parlamentu.

Przebieg procesu decyzyjnego, w którym zapadały rozstrzygnięcia o kształcie nowych instytucji, wykazał stosunkowo niski poziom orientacji, szczególnie wśród działaczy opozycyjnych w kwestii współczesnych instytucji demokratycznych ${ }^{10}$. Jednak w sprawach instytucji i procedur wyborczych izolacja od doświadczeń demokracji zachodnich miała także pozytywne konsekwencje. Skłoniła twórców systemu wyborczego do szukania własnych rozwiązań, przewidywania skutków pojawiających się propozycji, uwzględniania w kalkulacjach preferencji zarówno swoich, jak i przeciwnika. Koncepcja specyficznego projektu systemu mieszanego prawdopodobnie wynikała z dużej częstotliwości wizyt polityków bułgarskich $w$ innych krajach postkomunistycznych, nieco bardziej zaawansowanych w procesie zmian systemowych, a szczególnie w Polsce i na Węgrzech. Wydaje się, iż elita postkomunistyczna pozytywnie wartościowała model okresu przejściowego w Polsce i na Węgrzech, wykazując tym samym zainteresowanie procedurami wyborczymi stosowanymi w tych państwach ${ }^{11}$. Szczególnie przypadek węgierski, gdzie połączono dwie skrajne formuły wyborcze, mógł być inspirujący.

System mieszany równoległy w ówczesnej sytuacji decyzyjnej, odznaczającej się wysokim poziomem niepewności, związanej z pierwszymi postkomunistycznymi wyborami, miał co najmniej trzy zalety. Po pierwsze, umożliwiał uzyskanie mandatów w drodze dwóch sposobów; w okręgu jednomandatowym lub z listy partyjnej. Fakt, iż indywidualni kandydaci mogli startować w obydwu segmentach wyborczych, stwarzał poczucie bezpieczeństwa. Szczególnie było to ważne dla czołowych polityków głównych partii politycznych, którzy, w przypadku

${ }^{10}$ R. Nikolajew, Preparations for Free Elections of a Grand National Assembly, "Report on Eastern Europe”, 1990, vol. 1, nr 24 (15 czerwiec), s. 6-14; R. Kolarowa, D. Dimitrow, op. cit., s. 180.

${ }^{11}$ A.P. Melone, op. cit., s. 9. 
przegranej rywalizacji w swoim okręgu, mogliby dostać się do parlamentu z list partyjnych ${ }^{12}$. Po drugie, zastosowanie okręgów jednomandatowych pozwoliło BSP nie tylko na dyskontowanie wizerunku swej partii, ale również na podkreślanie profesjonalizmu, doświadczenia i innych cech osobowościowych jej kandydatów w znacznie większym stopniu, niż byłoby to możliwe w różnych wariantach wyłącznie systemu proporcjonalnego. W niektórych częściach kraju - zwłaszcza w rejonach wiejskich - wizerunek partii postkomunistycznej nie był obciążeniem, lecz w większych miastach komunistyczna przeszłość nie miała już tak pozytywnego wydźwięku. W takich okręgach wyborczych zatem BSP nie była zainteresowana eksponowaniem swego wizerunku. Partia ta w „niepewnych" okręgach wyborczych popierała nawet tzw. niezależnych kandydatów.

Podobnie jak w większości innych państw postkomunistycznych, atutem bułgarskich postkomunistów było to, że mieli kandydatów dobrze znanych wyborcom, większość reprezentantów opozycji była zaś zupełnie anonimowa. Nic dziwnego zatem, że w platformie wyborczej socjaliści eksponowali bardziej indywidualne cechy swoich kandydatów niż ogólny wizerunek swojej partii. Okręgi jednomandatowe stanowiły także szansę dla kandydatów niezależnych na zdobycie mandatów, a ekskomuniści najwidoczniej byli przekonani o tym, że deputowani niezależni będą ich sojusznikami. Wreszcie połączenie systemów w sposób równoległy ułatwiło prognozowanie prawdopodobnego wyniku wyborów, w przeciwieństwie do złożonego systemu węgierskiego. Można było także oczekiwać tego, że o całościowym rezultacie będą decydować wyniki w segmencie większościowym ${ }^{13}$.

W czasie debat Okrągłego Stołu SDS, chcąc wzmocnić potencjał wyborczy opozycji demokratycznej i zarazem zmniejszyć siłę zasobów organizacyjnych i personalnych BSP, dążyła do zwiększenia liczby mandatów w segmencie proporcjonalnym. Końcowa umowa, zawarta przy Okrągłym Stole 30 marca, mówiła o 400-osobowym Wielkim Zgromadzeniu Narodowym. Ustalono, że 200 deputowanych byłoby wybieranych z zastosowaniem większości bezwzględnej (tym samym w systemie dwóch tur głosowania) w okręgach jednomandatowych

\footnotetext{
12 Podobnie jak i na Węgrzech, ten „wentyl bezpieczeństwa” w 1990 roku okazał się istotny dla pokonanych w swoim okręgu wyborczym wysokiej rangi polityków, zwłaszcza tych z BSP; między innymi Minister Obrony Dobri Dzurow, rzecznik BSP Filip Bokow i Minister Kultury Krastyo Goranow przegrali w wyborach w okręgach jednomandatowych, ale zdobyli mandaty dzięki dostatecznie wysokiemu miejscu na liście swojej partii: S. Birch, Bulgaria: Engineering Legitimacy through Electoral System Design, [w:] Embodying Democracy. Electoral System Design in Post - Communist Europe, red. S. Birch, F. Millard, M. Popescu, K. Williams, Palgrave Macmillan, New York 2002, s. 112.

${ }^{13}$ J. Colomer, Handbook of Electoral System Choice, red. J. M. Colomer, B. Grofman, Palgrave Macmillan, New York 2004, s. 317-318.
} 
z wymogiem 50\% frekwencji wyborczej, a 200 z 28 okręgów wyborczych (pokrywających się z tradycyjnymi okręgami administracyjnymi Bułgarii) - w systemie proporcjonalnym z głosowaniem na listy partyjne zamknięte oraz z rozdziałem mandatów na poziomie ogólnokrajowym według metody d'Hondta i z 4-procentowym progiem wyborczym.

Względna łatwość, z jaką osiągnięto porozumienie, była także warunkowana faktem, iż wszyscy zainteresowani postrzegali powyższy system wyborczy jako rozwiązanie raczej tymczasowe ${ }^{14}$. Dodatkowym czynnikiem potencjalnie determinującym poczynania aktorów politycznych była świadomość, iż w przeciwieństwie do zwykłych legislatur w Wielkim Zgromadzeniu Narodowym większość ustawowej liczby posłów będzie niewystarczająca do podejmowania decyzji o randze ustaw konstytucyjnych. W tym przypadku wymagana była większość kwalifikowana (2/3). Żadna z głównych partii nie oczekiwała zdobycia $2 / 3$ mandatów w rezultacie zastosowania określonego systemu wyborczego (a ekskomuniści obawiali się nawet takiej ewentualności, ponieważ mogłaby ona podważyć legitymację reform konstytucyjnych realizowanych przez taki organ). W konsekwencji strony porozumienia miały świadomość, iż przyjęcie kolejnego systemu wyborczego będzie uwarunkowane koniecznością zawarcia następnego porozumienia. Inne byłoby nastawienie działaczy SDS czy ich ówczesnych sojuszników z BZNS, gdyby Wielkie Zgromadzenie Narodowe miało podejmować decyzje większością bezwzględną ${ }^{15}$.

Akt Wyborczy do Wielkiego Zgromadzenia Narodowego został uchwalony przez Zgromadzenie Narodowe 3 kwietnia, kiedy parlament wyznaczył też datę wyborów na 10 czerwca. Pod koniec rozmów Okrągłego Stołu podjęto także kompromis dotyczący prezydentury. BSP początkowo domagała się bezpośrednich wyborów prezydenckich, które miały być przeprowadzone jednocześnie z wyborami parlamentarnymi. Porozumienie, ostatecznie osiągnięte, zapowiadało wybór prezydenta (Peter Mładenow) przez Zgromadzenie Narodowe, którego kadencja miałaby trwać do końca funkcjonowania Wielkiego Zgromadzenia Narodowego ${ }^{16}$.

W trakcie wyborów parlamentarnych z 200 mandatów możliwych do zdobycia w okręgach jednomandatowych tylko 81 było przedmiotem rywalizacji

\footnotetext{
${ }^{14}$ R. Kolarowa, D. Dimitrow, op. cit., s. 199.

${ }^{15}$ Warto też odnotować, że BZNS, będący tzw. stronnictwem sojuszniczym komunistów, aż do 1989 roku opowiadała się za systemem przedstawicielstwa proporcjonalnego; M. Iordanowa, Electoral Law and the Electoral System, [w:] The 1990 Election to the Bulgarian Grand National Assembly and the 1991 Election to the Bulgarian National Assembly: Analyses, Documents and Data, red. G. Karasimeonow, Edition Sigma, Berlin 1997, s. 36.

${ }^{16}$ J. Gorzkowski, W. Morawski, op. cit., s. 105.
} 
w drugiej turze. Ostateczny rezultat oznaczał bezwzględną większość mandatów dla BSP (211 z 400), z których 114 zdobytych było w okręgach jednomandatowych, natomiast $97 \mathrm{z}$ list tejże partii. SDS zdobyła drugie miejsce z liczbą 114 mandatów, w tym 69 uzyskanych w okręgach i 75 z listy. BSP, jak przewidywano, uzyskała przewagę w okręgach jednomandatowych, ale oficjalne rezultaty pokazywały, że zyskała też więcej głosów na listy $(47,2 \%)$ niż SDS (36,2\%).

Należy zauważyć, że chociaż wynik i przebieg wyborów nie dawał BSP takiej legitymizacji, jakiej by mogła oczekiwać, to strategia negocjacyjna tego ugrupowania w procesie kształtowania systemu wyborczego była mocno uwarunkowana potrzebą takiej legitymizacji. Strona demokratyczna, jak się wydaje, uznawała potrzebę uzyskania takiej legitymacji przez BSP, oczekując w zamian ustępstw politycznych, począwszy od wyrzeczenia się monopolu na sprawowanie władzy ${ }^{17}$. Pomimo że początkowo proces reform ustrojowych w Bułgarii miał podobny charakter jak zmiany realizowane w ZSRR, to w trakcie rozmów Okrągłego Stołu scenariusz zmian politycznych (przyjęcie zasady pluralizmu politycznego, alternacji władzy oraz tym samym instytucjonalizacji opozycji) przypominał sytuację z innych państw Europy Środkowej. Rozpoczynając tak późno rozmowy „okrągłego stołu”, ich uczestnicy posiadali wiedzę o doświadczeniach zarówno polskich i węgierskich, jak i o wariancie rumuńskich ${ }^{18}$. Oznaczało to także, iż przynajmniej w tym aspekcie bułgarscy demokraci znajdowali się na o wiele lepszej pozycji negocjacyjnej. Jednak z powodu słabości organizacyjnej i braku szerszego poparcia społecznego nawet wynegocjowanie korzystnych rozwiązań instytucjonalnych było niewystarczające do odniesienia zwycięstwa wyborczego.

2. System proporcjonalny z 1991 roku jako rezultat transformacji systemowej

Wielkie Zgromadzenie Narodowe było już siódmym tego typu parlamentem w historii niepodległej Bułgarii i, podobnie jak poprzednie, miało przede wszystkim uchwalić nową konstytucję. Jednocześnie także WZN, uchwalając ustawy zwykłe, spełniało funkcje typowego parlamentu. Rozstrzygnięcia na temat prawa wyborczego musiały jednak poczekać aż do zakończenia debat konstytucyjnych.

Ostatecznie projekt konstytucji, nad którego przyjęciem debatowano głównie w maju i czerwcu 1991 roku, został przyjęty 12 lipca zdecydowaną większością głosów (309 na 400) deputowanych Wielkiego Zgromadzenia Narodowego. Konstytucja wprowadzała system demokracji parlamentarnej z bezpośrednio wybieranym prezydentem, niedysponującym jednak zbyt dużymi kompetencjami,

\footnotetext{
${ }^{17}$ R. Kolarowa, D. Dimitrow, op. cit., s. 194-197.

${ }^{18}$ Ibidem, s. 185.
} 
poza prawem weta zawieszającego ${ }^{19}$. Zgromadzenie Narodowe miało posiadać 240 deputowanych, wybieranych na kadencję czteroletnią. Prawo wyborcze nie zostało jednak skonstytucjonalizowane ${ }^{20}$.

Po uchwaleniu konstytucji Wielkie Zgromadzenie Narodowe zostało rozwiązane, kontynuowało jednak swoją działalność jako zwykły parlament do czasu kolejnych wyborów, których termin wyznaczono na wrzesień. Nie zdecydowano o utrzymaniu rozwiązań wyborczych przyjętych w 1990 roku do wyborów parlamentarnych w 1991 roku. Sytuację decyzyjną charakteryzował więc krótki czas na podjęcie decyzji dotyczącej nowego systemu wyborczego.

R. Kolarowa i D. Dimitrow rozróżniają cztery najważniejsze etapy w dwumiesięcznym procesie tworzenia systemu wyborczego: (1) okres pomiędzy 18 a 30 lipca, kiedy podjęto podstawowe decyzje dotyczące wprowadzenia zasady proporcjonalności; (2) okres pomiędzy 31 lipca a 22 sierpnia, kiedy postanowienia dotyczące procedur wyborczych były omawiane i następnie przyjęte na sesji plenarnej Zgromadzenia, po czym powyższa ustawa została zakwestionowana przez prezydenta (weto zawieszające w procesie promulgacji); (3) bunt opozycji 22 sierpnia przeciwko uzgodnionej formule rozdziału mandatów i (4) debata nad kolorem kart do głosowania, która trwała aż do momentu, gdy wprowadzono w tej kwestii poprawkę 12 września. Ta okresowość dostarcza dogodnego narzędzia heurystycznego dla poniższej analizy ${ }^{21}$.

Negocjacje w sprawie systemu wyborczego w 1991 roku, w porównaniu z rozmowami przy Okrągłym Stole, określane były przez inną sytuację decyzyjną. Już na początku debat parlamentarnych doszło do kompromisu w sprawie wprowadzenia formuły proporcjonalnej. Przyjęcie tego rozwiązania determinowało również rozmiar okręgów wyborczych. Wydaje się, że odejście od jednomandatowych okręgów wyborczych na rzecz wielomandatowych było w tym czasie popierane przez liderów socjalistów. Preferencje kierownictwa partii socjalistycznej w tej kwestii wynikały z chęci ograniczenia roli lokalnego (nie zawsze dyspozycyjnego wobec kierownictwa centralnego ${ }^{22}$ ) aparatu partyjnego. Okręgi jednomandatowe dotychczas niewątpliwie zwiększały rolę działaczy

19 Zob. szerzej: B. Dziemidok-Olszewska, Instytucja prezydenta w państwach Europy Środkowo-Wschodniej, Wydawnictwo UMCS, Lublin 2003, s. 161-166; J. Radew, Prezident Respubliki Botgarii, [w:] Ten Years of the Democratic Constitutionalism in Central and Eastern Europe, red. K. Działocha, R. Mojak, K. Wójtowicz, Wydawnictwo „Morpol”, Lublin 2001, s. 365-373.

${ }^{20}$ B. Szmulik, M. Żmigrodzki, System polityczny Butgarii, [w:] Systemy polityczne państw Europy Środkowej $i$ Wschodniej, Wydawnictwo UMCS, Lublin 2005, s. 175-177; J. Karp, M. Grzybowski, System konstytucyjny Butgarii, Wydawnictwo Sejmowe, Warszawa 2002, s. 16-21.

${ }^{21}$ R. Kolarowa, D. Dimitrow, op. cit., s. 194-197.

${ }^{22}$ Część terenowych struktur partyjnych nie akceptowała realizowanego kierunku przemian. Zob. szerzej: ibidem. 
lokalnych w procesie selekcji kandydatów. Dążenie do zwycięstwa wyborczego nie było w tym czasie jedynym motywem, którym kierowali się przywódcy BSP. Chodziło o zachowanie kontroli nad procesem selekcji kandydatów w wyborach i tym samym składu personalnego parlamentarzystów swojego klubu. Oficjalnie w retoryce politycznej pojawiały się wówczas argumenty o potrzebie demokratycznej legitymacji procedur wyborczych. Przeciwnicy polityczni socjalistów odrzucali koncepcję JOW z nieco innych powodów. Wynikało to przede wszystkim $\mathrm{z}$ dotychczasowych doświadczeń z wynikami wyborów $\mathrm{w}$ jednomandatowych okręgach wyborczych w 1990 roku. Politycy SDS grozili bojkotem wyborów w przypadku utrzymania w ordynacji wyborczej JOW w jakiejkolwiek formie. Wychodzili z założenia, że fałszerstwom wyborczym sprzyjały małe okręgi wyborcze, gdzie często zaledwie kilkuset wyborców mogło zmienić rezultat rywalizacji wyborczej. Taki proceder w okręgach dużych, ze względu na konieczność dokonywania manipulacji w skali tysięcy głosów, był już bardziej utrudniony.

W rezultacie powyższych preferencji głównych uczestników debaty parlamentarnej 30 lipca 1991 roku ustalono, że wybory parlamentarne będą się odbywać na podstawie dość typowego proporcjonalnego systemu wyborczego, z jednym poziomem alokacji mandatów w 31 okręgach wyborczych. Do transformacji głosów na mandaty postanowiono wykorzystać metodę największych liczb (d'Hondta). Rozwiązania powyższe okazały się trwałe, chociaż w późniejszych latach rozważano wprowadzenie formuły bardziej proporcjonalnej (metody największych reszt). W podziale mandatów mogły partycypować komitety wyborcze, które w skali kraju uzyskały co najmniej 4\% poparcia. Powyższy próg, w zależności od potencjału partii politycznej, był przedmiotem pewnych kontrowersji: jako zbyt niski lub, wprost przeciwnie, dyskryminujący mniejsze ugrupowania. W znacznym stopniu przyjęte zasady wyborcze powielały rozwiązania z segmentu proporcjonalnego z 1990 roku. Przedmiotem dyskusji była także kwestia struktury głosu. Pojawiały się propozycje głosowania preferencyjnego (system list otwartych). Jednak największe podmioty polityczne okazały zainteresowanie listami zamkniętymi, czyli tzw. systemem kategorycznym.

W okresie debaty nad ordynacją znacznie więcej emocji niż wymienione elementy systemu wyborczego wzbudziły kwestie dotyczące czynnego i biernego prawa wyborczego ${ }^{23}$. Uchwalona 14 sierpnia 1991 roku ordynacja wyborcza (więk-

${ }^{23}$ W świetle ustawy wyborczej uchwalonej przez WZN 20 sierpnia 1991 roku (dwa dni później znowelizowanej) czynne prawo wyborcze uzyskali wszyscy obywatele Republiki Bułgarii, którzy ukończyli 18 rok życia, z wyłączeniem postawionych w stan oskarżenia, odbywających karę pozbawienia wolności (art. 1). Bierne prawo wyborcze do parlamentu przysługuje obywatelom bułgarskim po ukończeniu 21 roku życia, z wykluczeniem posiadaczy podwójnego obywatelstwa, postawionych w stan oskarżenia, odbywających karę pozbawienia wolności (art. 2). 
szością 169 głosów „za”, 36 „przeciw”), z uwagi na pozbawienie prawa wyborczego Bułgarów przebywających za granicą, była ostro skrytykowana przez SDS - Ruch oraz przez prezydenta Żeliu Żelewa, który zastosował wobec tej ustawy nieskuteczne jednak prawo weta ${ }^{24}$. Socjaliści zdecydowanie opowiedzieli się za utrzymaniem kwestionowanych rozwiązań, próbując jednocześnie skierować zainteresowanie uczestników debaty na nowy, tym razem dwupoziomowy sposób repartycji mandatów (tzw. wariant Żana Widenowa). Rozdział mandatów miał się odbywać na poziomie okręgów wyborczych z zastosowaniem kwoty Hare'a. Pozostałe, nierozdzielone na poziomie okręgowym mandaty miały być przedmiotem alokacji na poziomie centralnym z zastosowaniem metody d'Hondta oraz utrzymaniem oficjalnego progu zaporowego na poziomie $4 \%{ }^{25}$. SDS zdecydowanie sprzeciwiła się próbom takich rozwiązań, argumentując, że ze względu na różną wielkość okręgów wyborczych nastąpi zróżnicowanie efektywnych progów zaporowych i w konsekwencji taki system wyborczy będzie miał charakter wyraźnie dyskryminujący dla średnich i słabszych ugrupowań politycznych. Groźba bojkotu wyborów ze strony SDS spowodowała powrót do wcześniejszej formuły wyborczej. Efektem tak osiągniętego kompromisu było pozostawienie rozwiązań dotyczących czynnego prawa wyborczego. Jako element formuły legitymizującej nową ordynację wyborczą można także potraktować kwestię kreowania Centralnej Komisji Wyborczej (CEC), decydującej między innymi o kolorze kart wyborczych ${ }^{26}$. Zgodnie bowiem z bułgarskimi tradycjami wyborczymi poszczególnym ugrupowaniom miały być przypisane różne, w zależności od opcji ideologicznej, kolory kart wyborczych, np. czerwony dla BSP, niebieski dla SDS itd ${ }^{27}$. W omawianym okresie bułgarski

Kandydatów na deputowanych mogły wysuwać partie polityczne, koalicje partyjne, ruchy i organizacje, zarejestrowane w trybie przewidzianym dla partii politycznych; kandydaci niezależni musieli się wykazać poparciem 2000 wyborców zamieszkałych w danym okręgu wyborczym (art. 41); „Dyrżawen Westnik”, 1991, nr 69/22.

${ }^{24}$ Jak się okazało, 20 sierpnia 1991 roku weto zostało uchylone.

${ }^{25}$ Republika Bulgariya, Sedmo Veliko Narodno Subranie, vol. 57, s. 128-137.

${ }^{26}$ Zob. szerzej: J. Karp, M. Grzybowski, op. cit., s. 28-29.

${ }^{27}$ Użycie kolorowych kart nawiązuje do dziewiętnastowiecznych tradycji demokratycznych. Od wyborów parlamentarnych w 1883 roku kolor niebieski był kolorem konserwatystów. Nieco później kolor pomarańczowy stał się kolorem agrariuszy (ludowców). Od roku 1990 karta wyborcza Związku Sił Demokratycznych jest koloru niebieskiego, a ludowców (BZNS) - koloru pomarańczowego. Praktyka dotychczas przeprowadzonych wyborów wykazała, że ugrupowanie, na które głosuje się za pomocą zielonych kart wyborczych, może liczyć na kilka tysięcy dodatkowych głosów. Przyczyną jest podobieństwo koloru niebieskiego i zielonego. Przekonała się o tym marginalna Partia Liberalna z Pernika, formalny „właściciel” zieleni, na którą przed laty głosowało znacznie więcej osób niż na inne tego rodzaju egzotyczne formacje. W. Petroff, Systemy wyborcze do parlamentów europejskich państw postkomunistycznych w latach 1990-1999, „Studia Polityczne”, 2002, nr 13, s. 210; M. Suchowiejko, Batalia o zieleń, „Kronika Sejmowa. Parlamenty Europy Środkowej i Wschodniej", 7 IV 1997. 
system partyjny był niestabilny. Posiadanie określonego koloru miało ułatwiać identyfikację na sfragmentaryzowanej scenie politycznej i tworzyć przesłanki dla instytucjonalizacji w dłuższej perspektywie czasowej. Decyzja o przyznaniu kolorów poszczególnym partiom została pozostawiona Centralnej Komisji Wyborczej, którą mianował prezydent (jej członkowie, chociaż w większości powiązani z partiami politycznymi, powinni posiadać kwalifikacje prawnicze). Kompetencja ta pozwoliła prezydentowi Żelju Żelewowi (wywodzącemu się $\mathrm{z}$ opozycji) uzyskać pewną kontrolę nad procesem wyborczym, co w intencji socjalistów miało równoważyć ich decydującą rolę w procesie stanowienia prawa wyborczego. Pozbywając się władzy związanej z administracją wyborczą, BSP uprzedzała tym samym potencjalne zarzuty o manipulacjach i nadużyciach wyborczych. Nowe mechanizmy co najmniej teoretycznie zmniejszały ryzyko znanych z wcześniejszych wyborów nadużyć. Powyższą argumentację należy potraktować zatem jako element działań BSP, zmierzających do uzyskania najkorzystniejszych dla siebie rozwiązań prawnych ${ }^{28}$.

Socjaliści zatem, posiadając większość w Zgromadzeniu (w sytuacji na dodatek postępującej dezintegracji opozycji), mogli przeforsować wiele korzystnych dla siebie rozwiązań w systemie wyborczym. W swoich preferencjach BSP była ograniczona jednak dwoma czynnikami. Po pierwsze, socjalistom zależało na utrzymaniu (przywróceniu) wiarygodności procesu wyborczego. Byli zatem gotowi spełnić żądania opozycji w pewnych kwestiach dotyczących administracji wyborczej. Po drugie, SDS, nie mogąc zrealizować swoich celów metodami konwencjonalnymi, podobnie jak i w czasie rozmów przy Okrągłym Stole, odwoływała się do groźby zerwania rozmów, bojkotu wyborów itp. Pozwoliło to na uzyskanie oczekiwanych rozwiązań w kwestii formuły wyborczej i rozmiaru okręgów. Istniał także obszar wspólnych interesów obydwu największych podmiotów bułgarskiej sceny politycznej. Ich preferencje często bywały rozbieżne z oczekiwaniami nowych uczestników gry politycznej. Przyjęte w ostatnich dniach obrad Zgromadzenia ustawy, dotyczące zwolnień podatkowych fundacji powiązanych z największymi partiami, podobnie jak i prawo o finansowaniu kampanii wyborczej, wyraźnie faworyzowały największe podmioty polityczne.

Wynik wyborów z października 1991 roku znamionował długo oczekiwaną przez środowiska opozycji demokratycznej porażkę BSP. Niemniej jednak SDS nie udało się zdobyć bezwzględnej większości. Demokraci uzyskali 34,4\% głosów w stosunku do 33,1\% zdobytych przez BSP. Wynik ten przekładał się na 110 mandatów dla SDS i 106 dla socjalistów. SDS utworzyła rząd koalicyjny z Ruchem na rzecz Praw i Swobód, który w nowym parlamencie kontrolował 24 mandaty.

${ }^{28}$ S. Birch, op. cit., s. 122. 
Wybory te powszechnie były uważane za wielki postęp pod względem ich uczciwości w porównaniu z głosowaniem w 1990 roku, potwierdzając tym samym przekonanie SDS, iż przyjęte $\mathrm{w}$ ramach systemu proporcjonalnego rozwiązania są bardziej demokratyczne i mniej narażone na manipulacje wyborcze.

\section{Stabilność i zmiany systemu wyborczego po roku 1991}

Pomiędzy 1991 a 2001 rokiem bułgarski system wyborczy odznaczał się rzadko spotykaną w państwach postkomunistycznych stabilnością. Większość zmian wprowadzonych do ordynacji wyborczych po 1991 roku zawierała szczegóły dotyczące administracji wyborczej, nie ingerując w mechanizmy systemu wyborczego ${ }^{29}$. Czynnikiem ograniczającym szanse dokonania zmian w systemie wyborczym był niewątpliwie fakt, że parlamenty wybierane przed 1997 rokiem kończyły swoją działalność w konsekwencji przedterminowych wyborów, co niewątpliwie utrudniało finalizację decyzji parlamentarnych w tej kwestii. Pomimo to jednak każde nowe wybory poprzedzone były wysiłkami mającymi na celu zmianę reguł systemu wyborczego.

Na przykład, kwestia reformy wyborczej została podjęta przez parlament w lecie i na jesieni 1994 roku. Pojawiły się wówczas żądania przedterminowych wyborów, które politycy BSP proponowali przeprowadzić na podstawie systemu mieszanego, znanego z wyborów w 1990 roku. Socjaliści proponowali powrót do mieszanego systemu wyborczego, który, jak sądzono, pomógłby im zdobyć bezwzględną większość, podobnie jak w roku 1990. Warunkiem powodzenia reformy wyborczej było przekonanie do tej koncepcji mniejszych partii politycznych. Pomimo początkowej aprobaty dla proponowanej zmiany przez kilka mniejszych ugrupowań centrowych (za cenę odłożenia wyborów aż do ustawowego zakończenia kadencji parlamentu), do porozumienia nie doszło w konsekwencji ujawnienia się kilku sprzeczności wśród ugrupowań parlamentarnych: między innymi próby BSP powiązania postulatu zmiany systemu wyborczego z nowelizacją konstytucji, ograniczającą kompetencje prezydenta, oraz narastającego przekonania wśród mniejszych partii, że silniejsze podmioty polityczne (w tym zdominowana przez nie Centralna Komisja Wyborcza) będą dążyć do takiego uregulowania procesu wyborczego, który ograniczy w efekcie dostęp do parlamentu mniejszym ugrupowaniom ${ }^{30}$.

${ }^{29}$ R. Rose, N. Munro, Elections and Parties in New European Democracies, Cambridge University Press, Washington 2003, s. 103-105.

${ }^{30}$ Bulgaria, "East European Constitutional Review", 1995, vol. 4, nr 1, s. 8. 
Koalicja wyborcza zbudowana na bazie BSP zdobyła w 1994 roku bezwzględną większość mandatów (52\%) nawet bez zastosowania systemu mieszanego ${ }^{31}$. Po wyborach parlamentarnych kwestia systemu mieszanego nie była już podejmowana. Nie wystąpiła żadna znacząca zmiana w istocie systemu wyborczego przed wyborami w 1997 roku $^{32}$. Wprawdzie 13 lutego 1997 roku, w ostatnim dniu swojej skróconej prawie o połowę kadencji, Zgromadzenie Narodowe znowelizowało ordynację wyborczą, to decyzja ta nie znalazła skutecznej implementacji wskutek weta zastosowanego przez wywodzącego się z SDS prezydenta Petera Stojanowa ${ }^{33}$. Najistotniejsza zmiana dotyczyła obniżenia progu upoważniającego do wejścia do parlamentu z $4 \%$ na $3 \%$ (była też propozycja progu $2 \%{ }^{34}$. Rozwiązanie takie przeforsowała lewica, która liczyła na to, iż dzięki temu w przyszłym parlamencie znajdą się ugrupowania stojące na lewo od centrum, uważane za potencjalnych koalicjantów BSP, przede wszystkim formująca się partia o orientacji eurolewicowej. Opozycja była stanowczo przeciwna tej zmianie, uznając ją za naruszenie osiągniętego z takim trudem kruchego porozumienia i wyrażając obawy, iż z tego powodu parlament będzie niestabilny ${ }^{35}$. Chociaż Zgromadzenie potrzebowało tylko większości bezwzględnej, aby obalić weto prezydenckie (i w ten sposób przeforsować reformę wyborczą), to nie miało okazji do takiego działania, ponieważ zostało rozwiązane 19 lutego, zanim weto prezydenckie zostało rozpatrzone ${ }^{36}$.

Wybory 19 kwietnia 1997 roku zakończyły się zdecydowanym sukcesem koalicji kierowanej przez SDS, która wygrała, otrzymując poparcie ponad 57\% wyborców i zdobywając 137 mandatów. Wola większości parlamentarnej do

${ }^{31}$ M. Suchowiejko, Wybory jak plebiscyt, „Rzeczpospolita” 19 XII 1994; M. Suchowiejko, Butgaria: triumf bytych komunistów. Propozycja powołania koalicji „Rzeczpospolita”, 20 XII 1994.

${ }^{32}$ Najważniejszą zmianą w prawie wyborczym, dokonaną za sprawą rządu kontrolowanego przez socjalistów, było rozdzielenie w 1995 roku przepisów dotyczących wyborów lokalnych od tych dotyczących wyborów parlamentarnych (od 1991 roku były one częścią tego samego aktu). Niektóre rozwiązania dotyczące wyborów samorządowych (dotyczące struktury administracyjnej) zostały jednak utrzymane w ordynacji do wyborów parlamentarnych, zmuszając wielokrotnie Centralną Komisję Wyborczą do interpretacji tego niezbyt spójnego prawa; S. Birch, op. cit., s. 124.

33 J. Jackowicz, Bułgaria, „Europa Środkowo-Wschodnia 1994-1995”, Instytut Studiów Politycznych PAN, Warszawa 1997, s. 323.

${ }^{34}$ J. Colomer, op. cit., s. 318.

${ }^{35}$ Inną nowością w nieskutecznej nowelizacji prawa wyborczego było wprowadzenie białych kart do głosowania zamiast kolorowych. Dziesięciokrotnie podniesiono także wysokość sumy, jaką mógł wydać kandydat na posła na cele kampanii wyborczej. Do tego czasu było to 300 tys. lewów (wówczas około 18 dolarów). Uchwalono także, iż wszystkie partie mają jednakowe prawa do czasu antenowego w publicznych mediach elektronicznych. Bułgaria. Obniżony próg wyborczy, „Kronika Sejmowa. Parlamenty Europy Środkowej i Wschodniej”, 18 II 1997.

${ }^{36}$ M. Suchowiejko, Pozostaje stary próg wyborczy, „Kronika Sejmowa. Parlamenty Europy Środkowej i Wschodniej", 4 III 1997. 
przyjęcia nowej ordynacji wyborczej, oficjalnie motywowana dążeniem do ujednolicenia przepisów prawa wyborczego, została sfinalizowana w kwietniu 2001 roku przed wyborami parlamentarnymi, które odbyły się w czerwcu tego roku $^{37}$. Reformę niewątpliwie ułatwiał fakt, że po raz pierwszy od 1991 roku parlament funkcjonował przez pełną czteroletnią kadencję. Uchwalenie ordynacji trzy dni przed zakończeniem kadencji Zgromadzenia Narodowego sprawiło, iż prezydent praktycznie nie mógł zastosować prawa weta. Inną przyczyną tej zwłoki była chęć maksymalnego utrudnienia wejścia na scenę polityczną byłemu carowi Symeonowi II na czele utworzonego przez niego Ruchu Narodowego Symeon II.

Zgromadzenie rozpatrywało siedem projektów i ten, który ostatecznie został przyjęty (projekt przygotowany przez Centralną Komisję Wyborczą), przyniósł niewiele zmian do istniejącego systemu wyborczego. Po raz kolejny przedstawiona propozycja BSP wprowadzenia systemu mieszanego, podobnie jak i trzyprocentowego progu ustawowego oraz głosowania preferencyjnego na listy otwarte została odrzucona. Projekt CKW wprowadzenia wymogu zbierania podpisów przez nowe partie polityczne także nie wytrzymał konfrontacji z protestami opozycji. Istniały już bowiem dosyć restrykcyjne procedury rejestracji partii na podstawie nowego prawa o partiach, a wprowadzenie dodatkowych przeszkód w procesie wyborczym uważano za rażący sposób powstrzymania nowych, popularnych wówczas partii monarchistycznych od udziału w wyborach. Nowa ordynacja wyborcza utrzymywała rozwiązanie z kolorowymi kartami do głosowania pomimo faktu, że zostały one zniesione dla wyborów lokalnych wraz z reformą 1995 roku i pomimo zaleceń obserwatorów międzynarodowych z OBWE ${ }^{38}$. Procedury rozdziału mandatów na etapie państwowym oraz wysokość progu ustawowego pozostały niezmienione. Głównym osiągnięciem nowego prawa było wyjaśnienie i zracjonalizowanie administracyjnych procedur wyborczych (choć to nie zapobiegło zarzutom o manipulacji ze strony opozycji ${ }^{39}$.

${ }^{37}$ M. Suchowiejko, Butgaria: Nowa ordynacja wyborcza, „Kronika Sejmowa. Parlamenty Europy Środkowej i Wschodniej”, 31 I 2001, s. 3-4; „Dyrżawen Westnik”, nr 37/13 IV 2001.

${ }^{38}$ OSCE, Final Report: OSCE/ODIHR International Observer Mission: Bulgarian Parliamentary Elections, 19 April 1997, Warsaw 1997, s. 2-3.

${ }^{39}$ Krytykowaną nowością w ordynacji było obciążenie partii i koalicji kosztem druku kart do głosowania. Każde ugrupowanie wystawiające swoich kandydatów we wszystkich okręgach wyborczych musiałoby więc zapłacić równowartość kilkunastu tysięcy dolarów za druk swoich kart w liczbie 7,5 mln sztuk. Na wniosek 61 posłów opozycji Sąd Konstytucyjny uchylił teksty nowej ordynacji wyborczej, zgodnie z którymi partie polityczne, startujące w wyborach, miały pokryć koszt druku swoich kart do głosowania. Zob. szerzej uzasadnienie: M. Suchowiejko, Trybunat Konstytucyjny: karty do głosowania na koszt budżetu, „Kronika Sejmowa. Parlamenty Europy Środkowej i Wschodniej", 2001, nr 76, s. 4. 
Wysoki poziom stabilności bułgarskiego systemu wyborczego w okresie pierwszej dekady procesu transformacji można wyjaśniać zdominowaniem bułgarskiej sceny partyjnej przez dwa silne ugrupowania, które były zainteresowane utrzymaniem systemu, jaki pozwoliłby im w najgorszym przypadku na przemian sprawować władzę $e^{40}$. Sytuacja zmieniła się jednak radykalnie i dramatycznie, kiedy w rezultacie wyborów z czerwca 2001 roku połowę mandatów w parlamencie uzyskała nowa populistyczno-monarchistyczna formacja polityczna, która koncentrowała się wokół Symeona Saksekoburggotskiego, byłego cara Bułgarii ${ }^{41}$. Późniejsze zwycięstwo kandydata BSP - Georgi Pyrwanowa - w wyborach prezydenckich oraz stopniowy spadek popularności rządzącego Ruchu Narodowego Symeona II (NDSV) spowodowały, że bułgarska scena polityczna zaczęła ewoluować wówczas w kierunku systemu ekstremalnie wielopartyjnego $\mathrm{z}$ równowagą pomiędzy partiami ${ }^{42}$.

Wyniki wyborów parlamentarnych, zwłaszcza z 2001 roku, powszechnie interpretowano jako wskaźnik niezadowolenia obywateli Bułgarii z partii politycznych, co dało pretekst do debaty o potrzebie ponownego rozpatrzenia postulatu głosowania preferencyjnego na listy otwarte. Członkowie NDSV poparli to rozwiązanie w momencie, gdy oficjalnie Ruch przekształcił się w kwietniu 2002 roku w partię polityczną ${ }^{43}$. Wśród innych ugrupowań postulat ten w tym czasie także znajdował wielu zwolenników ${ }^{44}$. Postępujący spadek poparcia dla ugrupowania byłego cara odsunął tę kwestię jednak na czas późniejszy.

Nowelizacja ordynacji wyborczej z 2001 roku miała miejsce 11 kwietnia $2005 \mathrm{roku}^{45}$. Przyjęte wówczas rozwiązania nie zmieniały jednak zasadniczych cech proporcjonalnego systemu wyborczego. Nowością było odejście od kolorowych kart do głosowania i wprowadzenie kart jednolitych w kolorze białym (art. 74). Tym samym deputowani wyrażali przekonanie, że bułgarski system partyjny jest już ustabilizowany, natomiast poszczególne jego elementy składowe są rozpoznawane przez wyborców. Niezbyt głośno artykułowane postulaty o potrzebie zamknięcia systemu partyjnego realizowało kolejne nowe rozwiązanie, czyli kaucje (depozyty) wyborcze dla kandydatów. Proponowane już kilka lat

${ }^{40}$ E. Pioskowik, Butgaria. Rola organów przedstawicielskich $w$ systemie rząów na szczeblach centralnym i terenowym, [w:] Dynamika systemów politycznych wybranych państw Europy Środkowej $i$ Wschodniej, red. M. Barański, Wydawnictwo Uniwersytetu Śląskiego, Katowice 1995, s. 26.

${ }^{41}$ M. Suchowiejko, Butgaria: Simeon czeka jak generat de Gaulle, „Rzeczpospolita”, 6 I 1995.

${ }^{42}$ M. Suchowiejko, Staba herbata zamiast heroiny, „Rzeczpospolita”, 30 VII 2002.

${ }^{43}$ S. Birch, op. cit., s. 125.

${ }^{44}$ Ibidem.

45 „Dyrżawen Westnik”, nr 32/12 IV 2005. 
wcześniej depozyty przewidywały konieczność wpłaty przez komitety wyborcze partii politycznych 20 tys. lewa. Z kolei komitety koalicyjne zobowiązane były do uiszczenia sumy 40 tys. lewa.

Przeprowadzone kilka miesięcy później wybory parlamentarne przyniosły sukces Koalicji na rzecz Bułgarii (31.0\%) tworzonej przez Bułgarską Partię Socjalistyczną oraz inne mniejsze partie lewicowe. Rządzące dotychczas NSDV, będące zapleczem politycznym dotychczasowego premiera Symeona Saksekoburggotskiego, zdobyło zaledwie niespełna 20,0\% głosów i w następnych latach ulegało dalszej dezintegracji. Nowym relewantnym, zaliczanym do centroprawicowych, podmiotem na bułgarskiej scenie politycznej stał się ruch polityczny (następnie zarejestrowany jako partia polityczna) pod nazwą Obywatele na rzecz Europejskiego Rozwoju Bułgarii (GERB). GERB stanowił, począwszy od drugiej części pierwszej dekady XXI wieku, główną (obok socjalistów) siłę na bułgarskiej scenie politycznej. System partyjny zachował cechy ekstremalnie wielopartyjnego z dwiema partiami dominującymi (GERB i BSP). Zwykle jednak po wyborach rządy tworzone przez zwycięskie ugrupowanie miały charakter koalicyjny lub mniejszościowy.

$\mathrm{Na}$ fali społecznego niezadowolenia $\mathrm{z}$ funkcjonowania dotychczasowych mechanizmów alternacji władzy ( $w$ konsekwencji których co cztery lata do władzy powracali ekskomuniści) oraz rozczarowania społecznymi skutkami realizowanej polityki gospodarczej w kolejnych latach zarówno wśród klasy politycznej, jak i środowisk niereprezentowanych w parlamencie, pojawiały się między innymi postulaty zmiany ordynacji wyborczej. 22 kwietnia 2009 roku, na trzy miesiące przed wyborami, Zgromadzenie Narodowe uchwaliło nową ordynację wyborczą ${ }^{46}$. Najważniejsza zmiana dotyczyła zmiany formuły wyborczej z proporcjonalnej na mieszaną (proporcjonalno-większościową). Zdecydowano, że 209 deputowanych zostanie wybranych według formuły proporcjonalnej $\mathrm{w}$ wielomandatowych okręgach wyborczych, natomiast 31 - według zasad systemu z zasadą większości względnej w jednomandatowych. Terytorium kraju podzielono na 31 okręgów wyborczych, pokrywających się z funkcjonującymi w ramach podziału administracyjnego obwodami Bułgarii, przy czym Sofię podzielono na trzy okręgi, w obwodzie płowdijskim zaś wydzielono miasto Płowdiw i obszar pozamiejski. We wszystkich okręgach wyborczych głosujący wybierali kandydatów z regionalnej listy proporcjonalnej oraz jednego kandydata $\mathrm{z}$ regionalnej listy większościowej. Mandaty w segmencie proporcjonalnym były obliczane z zastosowaniem korzystnej dla mniejszych komitetów wyborczych

${ }^{46}$ Poprawki i uzupełnienia do Ustawy o wyborach reprezentantów do Zgromadzenia Narodowego, „Dyrżawen Westnik”, nr 31/24 IV 2009. 
metody kwotowej (Hare'a-Niemeyera), natomiast z listy w segmencie większościowym $\mathrm{w}$ jednomandatowym okręgu wyborczym automatycznie do parlamentu dostawał się kandydat z największą liczbą głosów. W ramach przyjętego wariantu systemu mieszanego zdecydowana większość mandatów pochodziła z segmentu proporcjonalnego. Wyborcy mogli decydować jedynie w 31 jednomandatowych okręgach wyborczych o wyborze personalnym. Niewątpliwie dla, posiadającej jeszcze wówczas większość, lewicy postkomunistycznej zmiana systemu wyborczego była próbą obrony swojej pozycji w zbliżającej się elekcji parlamentarnej. Kierowano się przy tym podobnymi jak na początku lat dziewięćdziesiątych przesłankami oceny swoich szans wyborczych, dodatkowo opartych także na prawie dwudziestoletnich doświadczeniach rywalizacji wyborczej w ramach różnych mechanizmów prawnych.

Przedmiotem gry politycznej okazała się również kwestia ustawowego progu wyborczego. Głosami rządzącej koalicji oraz ugrupowań nacjonalistycznych Zgromadzenie Narodowe uchwaliło również poprawkę, zakładającą podniesienie progu wyborczego dla koalicji z $4 \%$ do $8 \%{ }^{47}$. Przeciwko temu rozwiązaniu zaprotestowały balansujące na granicy progu partie prawicowe i ludowe zgromadzone w tzw. Niebieskiej Koalicji, które oskarżyły rządzących o samowolną i niedemokratyczną próbę wyeliminowania przeciwników politycznych z udziału w wyborach. Wyborczy wynik prawicy mógł być o tyle istotny dla konstrukcji przyszłego rządu: liderzy prowadzącej we wszystkich sondażach partii GERB podkreślali, że - jeśli nie zdobędą bezwzględnej większości głosów jedynym partnerem, z którym będą rozmawiać o powołaniu wspólnego gabinetu, będzie właśnie Niebieska Koalicja. Stanowczo zaprzeczali, że istnieje możliwość utworzenia rządu z socjalistami. Zresztą także ówczesny premier i lider BSP Sergiej Staniszew zastrzegł, że nie widzi możliwości współpracy z GERB-em. Poprawkę do systemu wyborczego, w oczywisty sposób uderzającą w opozycję, skrytykowali niektórzy członkowie BSP, między innymi wicepremier i minister spraw zagranicznych Iwajło Kajfin. Przeciwko zmianie opowiedział się również prezydent G. Pyrwanow (były lider BSP), który 15 kwietnia zgłosił wobec niej weto. Jednakże tydzień później parlament weto odrzucił i dopiero decyzja Trybunału Konstytucyjnego, który 12 maja anulował nowelę, definitywnie rozwiązała problem podwyższenia progu wyborczego. Ordynacja z 2009 roku nie tylko utrzymała, lecz nawet podwyższyła wymaganą sumę depozytu wyborczego (50 tys. lewa dla partii politycznych, 100 tys. dla koalicji, 15 tys. dla indywidualnych kandydatów). Nieoficjalną intencją tych przepisów było utrudnienie nowym podmiotom politycznym inkluzji na poziomie parlamentarnym.

\footnotetext{
${ }^{47}$ „Dyrżawen Westnik”, nr 34/8 V 2009.
} 
Wybory przeprowadzone w oparciu o system mieszany przyniosły 5 lipca 2009 roku zwycięstwo Obywatelom na rzecz Europejskiego Rozwoju Bułgarii. Po raz kolejny Bułgarzy ulokowali swoje nadzieje w podmiocie wyborczym podejmującym rywalizację z pozycji partii pozaparlamentarnej. Jednym z zadań nowego parlamentu była reforma przepisów wyborczych, a zwłaszcza ich unifikacja w kodeksie wyborczym. W debatach parlamentarnych proponowano również zmianę formuły wyborczej oraz sposobów wyrażania swoich preferencji przez wyborców. Wprowadzony w 2009 roku w wyborach do Zgromadzenia Narodowego (po raz drugi w historii politycznej Bułgarii) system mieszany został zmieniony. W przyjętym 27 stycznia 2011 roku kodeksie wyborczym powrócono do formuły proporcjonalnej dokonywania alokacji mandatów w wielomandatowych okręgach wyborczych (od czterech do szesnastu mandatów) oraz - co było nowością w dotychczasowej historii bułgarskich rozwiązań wyborczych - systemu preferencyjnego ${ }^{48}$. Tym samym wyborcy głosowali na listy partyjne, zaznaczając na nich swoją preferencję personalną (tzw. listy otwarte). Mandaty dla komitetów wyborczych, które przekroczyły wymagany na poziomie ogólnokrajowym próg 4\%, dzielone były według przyjętej w 2009 roku metody Hare'a-Niemeyera. Obniżeniu uległ depozyt wyborczy (do 10 tys. lewa) dla komitetów wyborczych.

W kolejnych latach w Bułgarii miał miejsce kryzys polityczny. Niezadowolenie $\mathrm{z}$ funkcjonowania systemu politycznego wyrażali obywatele $\mathrm{w}$ trakcie licznych demonstracji ulicznych. Kontestowano między innymi mechanizmy selekcji klasy politycznej, krytykując również obowiązujące mechanizmy wyborcze. Pojawiały się społeczne inicjatywy zmiany ordynacji wyborczej. Na przykład jednym $\mathrm{z}$ inicjatorów referendum $\mathrm{w}$ sprawie wprowadzenia systemu większościowego był popularny shawman Sławi Trufonow. Inicjatywę także popierał zabiegający o reelekcję (wywodzący się z GERB) prezydent Rosen Plewnelijew. W 2014 roku prezydent zaapelował do obywateli, aby to oni zdecydowali pomiędzy większościowym a proporcjonalnym systemem wyborczym obowiązkowym głosowaniem w wyborach oraz możliwością głosowania elektronicznego ${ }^{49}$. Apel

\footnotetext{
${ }^{48}$ Kodeks wyborczy, „Dyrżawen Westnik”, nr 9/28 I 2011.

${ }^{49}$ Popierający reformę systemu wyborczego podkreślali, że obowiązek udziału w wyborach może zapobiec powszechnemu kupowaniu głosów, co według miejscowych analityków i międzynarodowych obserwatorów, między innymi OBWE, miało miejsce podczas wszystkich wyborów ostatnich lat w Bułgarii - parlamentarnych, prezydenckich i samorządowych. Kupowanie głosów było powszechne zwłaszcza wśród społeczności romskich. Elektroniczne głosowanie pozwoliłoby około $1 \mathrm{mln}$ Bułgarów, przebywającym na emigracji, na udział w wyborach parlamentarnych i prezydenckich, a wprowadzenie systemu większościowego z JOW - jak twierdzili zwolennicy tego rozwiązania - dałoby szansę na wejście do polityki osobom niezwiązanym z tra-
} 
prezydenta do obywateli był spowodowany tym, że głowa państwa w Bułgarii nie ma możliwości inicjatywy ustawodawczej. Inicjatywę prezydenta poparł komitet obywatelski zrzeszający uczestników antyrządowych protestów. Organizacją zbiórki podpisów zajęła się także opozycyjna wówczas partia GERB. Zebrano wymagane ponad 500 tys. głosów. Jednak parlament zdominowany przez koalicję lewicowej BSP i partii etnicznych Turków Ruch na rzecz Praw i Swobód nie poparł wówczas inicjatywy referendalnej.

Po wygranych przez GERB wyborach w 2014 roku prezydent w kolejnym roku ponownie zainicjował proces przeprowadzenia referendum. Tym razem akcja zbierania podpisów została przeprowadzona przez ruch społeczny kierowany przez S. Trufanowa. Bułgarzy mieli odpowiedzieć na sześć pytań, dotyczących zmiany obecnego systemu wyborczego z proporcjonalnego na większościowy, zmniejszenia liczby deputowanych z 240 do 120, wprowadzenia obowiązku udziału w wyborach, umożliwienia elektronicznego głosowania oraz bezpośredniego wyboru regionalnych szefów sił bezpieczeństwa ${ }^{50}$. Parlament zatwierdził te pytania, jednak prezydent Rosen Plewnelijew zaskarżył część z nich do Trybunału Konstytucyjnego. Według głowy państwa część pytań dotyczy zmian systemowych w strukturach władz, a takie zmiany może dokonywać wyłącznie Ustawodawcze Zgromadzenie Narodowe. Ostatecznie po orzeczeniu TK zostały trzy pytania - o zmianę systemu proporcjonalnego na większościowy, o obowiązkowe głosowanie oraz o dotacje dla partii politycznych. Ostatecznie referendum odbyło się 6 listopada 2016 roku. Według CKW na pierwsze i trzecie pytanie padło ok. 71\% odpowiedzi „tak”, na drugie - 62\%. Wyniki referendum nie były jednak wiążące z powodu nieznacznie niższej od wymaganej frekwencji wyborczej ${ }^{51}$. Oznaczało to, że te trzy pytania zostały skierowane do parlamentu. W jednej z kwestii - o obowiązkowe głosowanie - zapadła decyzja pozytywna. Obowiązek głosowania wprowadzono w znowelizowanej wiosną 2016 roku or-

dycyjnymi, dużymi partiami. Zob. szerzej: What is Bulgaria's voting system referendum about?; http://www.novinite.com/articles, dostęp 16 IX 2017.

${ }^{50}$ Jedno z pytań dotyczyło zmiany systemu finansowania partii politycznych. Obecnie wszystkie partie, które otrzymały powyżej 1\% głosów w wyborach parlamentarnych, otrzymują dotację w wysokości 11 BGN (ok. 6 euro) rocznie za każdy oddany na nie głos. Inicjatorzy referendum proponowali zmniejszenie tej kwoty do 1 BGN (50 eurocentów); Wybory prezydenckie w Butgarii połaczone z referendum; http//:http://www.polskieradio.pl/5/3/Artykul/1649009, dostęp 16 IX 2017.

${ }^{51}$ Zabrakło ok. 13 tys. głosów. W Bułgarii wyniki referendum są wiążące, jeżeli frekwencja w nim była wyższa niż frekwencja w ostatnich wyborach parlamentarnych. Zob. szerzej: Butgaria: Referendum w sprawie zmiany ordynacji wyborczej nieważne, „Gazeta Prawna”, 8 II 2016, http:// http://www.gazetaprawna.pl/artykuly, dostęp 16 IX 2017. 
dynacji wyborczej5 ${ }^{52}$ W zasadniczej dla mechanizmów wyborczych kwestii, czyli wprowadzenia sytemu większościowego (podobnie jak w sprawie ograniczenia dotacji dla partii politycznych), deputowani wybrani zgodnie z obowiązującym obecnie systemem proporcjonalnym $\mathrm{z}$ list partyjnych, nie wyrazili swojego poparcia.

\section{Zakończenie}

W okresie ponad ćwierćwiecza od upadku systemu komunistycznego w Bułgarii testowano różne systemy wyborcze. Poniższa tabela jest ilustracją tego zjawiska.

Tabela 1

Ewolucja systemu wyborczego w Butgarii po 1990 roku

\begin{tabular}{|l|l|l|l|c|}
\hline Rok wyborów & $\begin{array}{l}\text { Typ systemu } \\
\text { wyborczego }\end{array}$ & $\begin{array}{l}\text { Struktura okręgów } \\
\text { wyborczych }\end{array}$ & \multicolumn{1}{|c|}{ Formuła wyborcza } & Próg wyborczy \\
\hline 1990 & mieszany & $\begin{array}{l}200 \mathrm{JOW} \\
28 \mathrm{WOW}\end{array}$ & $\begin{array}{l}\text { w JOW - w.b./DTG } \\
\text { pr: d' Hondt }\end{array}$ & $4 \%$ \\
\hline $1991-2005$ & pr & $\begin{array}{l}31 \text { WOW } \\
\text { (rozmiar 4-13) }\end{array}$ & d'Hondt & $4 \%$ \\
\hline 2009 & mieszany & $\begin{array}{l}31 \text { JOW } \\
31 \text { WOW }\end{array}$ & $\begin{array}{l}\text { JOW - w.w. } \\
\text { WOW - Hare'a-Nie- } \\
\text { meyera }\end{array}$ & $4 \%$ \\
\hline $2013-2017$ & pr & $\begin{array}{l}31 \text { WOW } \\
\text { (rozmiar 4-16) }\end{array}$ & Hare'a-Niemeyera & $4 \%$ \\
\hline
\end{tabular}

Objaśnienia: * - dystrybucja mandatów na poziomie ogólnokrajowym; JOW - jednomandatowe okręgi wyborcze; WOW - wielomandatowe okręgi wyborcze; pr - system proporcjonalny; DTG - system dwóch tur głosowania.

Żródło: opracowania własne.

Preferencje partii politycznych w kwestii wyboru określonych elementów systemu wyborczego w różnym czasie obejmowały takie cele, jak: a) legitymizacja procesu demokratyzacji (w związku z tym uznawano przewagę systemu proporcjonalnego); b) zwiększenie poziomu inkluzji politycznej w celu zbudowania systemu opartego na pluraliźmie politycznym i ewentualnego zwiększenia szans mniejszych (najczęściej koalicyjnych) partii politycznych (co przejawiało się w dążeniu do obniżaniu progów naturalnych i zwłaszcza ustawowych); c) szukanie szans na

${ }^{52}$ Bulgarian Parliament Approves Introduction of Compulsory Voting; http:// www.novinite.com/articles, dostęp 16 IX 2017. 
zwycięstwo poprzez eksponowanie wizerunku popularnych kandydatów (co pozwalał uzyskać system JOW); d) kreowanie wizerunku partii politycznych (co było motywem polityków centroprawicowych popierających system pr i głosowanie na listy zamknięte) itp. W coraz większym stopniu głównym motywem wyboru określonych rozwiązań wyborczych jest maksymalizacja wyniku wyborczego.

\section{Bibliografia}

\section{Dzienniki urzędowe}

- „Dyrżawen Westnik”, nr 69/22 VIII 1991.

- „Dyrżawen Westnik”, nr 37/13 IV 2001

- „Dyrżawen Westnik”, nr 32/12 IV 2005.

- „Dyrżawen Westnik”, nr 31/24 IV 2009.

- „Dyrżawen Westnik”, nr 34/8 IV 2009.

- „Dyrżawen Westnik”, nr 9/28 IV 2011.

Artykuły i monografie

- Ashley S., Bulgaria, "Electoral Studies", 1990, vol. 9, nr 4.

- Bell J.D., Bulgaria, [w:] Developments in East European Politics, red. S. White, J. Batt, P. Lewis, Cambridge University Press, Basingstoke 1993.

- Bell J.D., Democratization and Political Participation in Post-Comminist Bulgaria, [w:] Politics, Power and the Struggle for Democracy in South - East Europe, red. K. Dawisha, B. Parrott, Plograve, Baltimore 1997.

- Biagini A., Guida F., Pót wieku realnego socjalizmu: Europa Środkowowschodnia od II wojny światowej do upadku rzaadów komunistycznych, Wydawnictwo Wyższej Szkoły Pedagogicznej, Rzeszów 1998.

- Birch S., Bulgaria: Engineering Legitimacy through Electoral System Design [w:] Embodying Democracy. Electoral System Design in Post - Communist Europe, red. S. Birch, F. Millard, M. Popescu, K. Williams, Plograve, New York 2002.

- Bulgaria, "East European Constitutional Review", 1995, vol. 4, nr 1.

- Butgaria. Obniżony próg wyborczy, „Kronika Sejmowa. Parlamenty Europy Środkowej i Wschodniej", 18 II 1997.

- Centkowska E., Jesień Ludów'89. Kalendarium wydarzeń, Wydawnictwa Szkolne i Pedagogiczne, Warszawa 1992.

- Colomer J., Handbook of Electoral System Choice, red. J.M. Colomer, B. Grofman, New York 2004.

- Dziemidok-Olszewska B., Instytucja prezydenta w państwach Europy Środkowo-Wschodniej, Wydawnictwo UMCS, Lublin 2003.

- Gawrilow V., Communist Party and Opposition Sign Key Political Agreements, "Report on Eastern Europe", 1990, vol. 1.

- Gorzkowski J., Morawski W., Jesień narodów, Oficyna Wydawnicza Volumen, Warszawa 1991. 
- Iordanova M., Electoral Law and the Electoral System, [w:] The 1990 Election to the Bulgarian Grand National Assembly and the 1991 Election to the Bulgarian National Assembly: Analyses, Documents and Data, red. G. Karasimeonow, Edition Sigma, Berlin1997.

- Jackowicz J., Butgaria, „Europa Środkowo-Wschodnia 1994 -1995”, Wydawnictwo Sejmowe, Warszawa 1997.

- Karp J., Grzybowski M., System konstytucyjny Butgarii, Warszawa 2002.

- Kolarowa R., Dimitrow D., The Roundtable Talks in Bulgaria, [w:] The Roundtable Talks and the Breakdown of Communism, red. J. Elster, University of Chicago Press, Chicago-London 1996.

- Magdalenka po butgarsku, „Gazeta Wyborcza”, 31 III-1 IV 1990.

- Melone A.P., Bulgaria's National Roundtable Talks and the Politics of Accomodation: Creating Parliamentary Government: The Transition to Democracy in Democracy in Bulgaria, red. A.P. Melone, Edition Sigma, Columbus 1998.

- Nikolaew R., Political Maneuvering Before the Round-table Talks, "Report on Eastern Europe", 1990, vol. 1.

- Nikolajew R., Preparations for Free Elections of a Grand National Assembly, "Report on Eastern Europe", 1990, vol. 1, nr 24 (15 czerwiec).

- Orlikowski M., Siadaja do stotu, „Gazeta Wyborcza”, 3 I 1990.

- Petroff W., Systemy wyborcze do parlamentów europejskich państw postkomunistycznych w latach 1990-1999, „Studia Polityczne”, 2002, nr 13.

- Pioskowik E., Butgaria. Rola organów przedstawicielskich w systemie rzadów na szczeblach centralnym i terenowym, [w:] Dynamika systemów politycznych wybranych państw Europy Środkowej $i$ Wschodniej, red. M. Barański, Wydawnictwo Uniwersytetu Śląskiego, Katowice 1995.

- Radew J., Prezident Respubliki Botgarii, [w:] Ten Years of the Democratic Constitutionalism in Central and Eastern Europe, red. K. Działocha, R. Mojak, K. Wójtowicz, Wydawnictwo „Morpol”, Lublin 1999.

- Rose R., Munro N., Elections and Parties in New European Democracies, Cambridge University Press, Washington 2003.

- Suchowiejko M., Batalia o zieleń, „Kronika Sejmowa. Parlamenty Europy Środkowej i Wschodniej", 7 IV 1997.

- Suchowiejko M., Butgaria: Nowa ordynacja wyborcza, „Kronika Sejmowa. Parlamenty Europy Środkowej i Wschodniej”, 31 I 2001.

- Suchowiejko M., Butgaria: Simeon czeka jak generat de Gaulle, „Rzeczpospolita”, 6 I 1995.

- Suchowiejko M., Bułgaria: triumf bytych komunistów. Propozycja powołania koalicji „Rzeczpospolita”, 20 XII 1994.

- Suchowiejko M., Pozostaje stary próg wyborczy, „Kronika Sejmowa. Parlamenty Europy Środkowej i Wschodniej", 4 III 1997.

- Suchowiejko M., Staba herbata zamiast heroiny, „Rzeczpospolita”, 30 VII 2002.

- Suchowiejko M., Trybunat Konstytucyjny: karty do głosowania na koszt budzetu, „Kronika Sejmowa. Parlamenty Europy Środkowej i Wschodniej”, 31 I 2001.

- Suchowiejko M., Wybory jak plebiscyt, „Rzeczpospolita”, 19 XII 1994. 
- Szmulik B., Żmigrodzki M., System polityczny Bułgarii, [w:] Systemy polityczne państw Europy Środkowej $i$ Wschodniej, Wydawnictwo UMCS, Lublin 2005.

- Wojnicki J., Trudna droga do demokracji. Europa Środkowo-Wschodnia po 1989 roku, Wydawnictwo Autorskie, Warszawa 2002.

- Żmigrodzki M., Przeobrażenia polityczno-ustrojowe i Sąd Konstytucyjny w Bułgarii, Wydawnictwo UMCS, Lublin 1997.

Streszczenie: W Bułgarii w wyborach do Zgromadzenia Narodowego w okresie demokratyzacji systemu politycznego wykorzystywane były różne mechanizmy wyborcze. Pierwsze tranzycyjne wybory parlamentarne zostały przeprowadzone w oparciu o system mieszany. Następnie wykorzystywany był system proporcjonalny, z wyjątkiem wyborów w 2009 roku, w których zastosowano znów system mieszany. Formuła proporcjonalna w dalszym ciągu jest obowiązującym rozwiązaniem w bułgarskim kodeksie wyborczym pomimo kilkukrotnych prób jej zmiany, między innymi poprzez referendum. W polityce reform wyborczych główną rolę w tym państwie odgrywały partie polityczne.

Słowa kluczowe: Bułgaria, wybory, systemy wyborcze, partie polityczne

Politics of Reforms of Electoral Systems for the National Assembly in Bulgaria in 1990-2016

Summary: In Bulgaria, various electoral mechanisms were used in elections to the National Assembly during the democratization of the political system. The first transit parliamentary elections were conducted on the basis of a mixed system. Then, the proportional system was used, with the exception of the 2009 election in which the mixed system was used again. The proportional formula is still a binding option in the Bulgarian electoral code despite several attempts to change it, among others, by referendum. In this issue, political parties played a major role in the country.

Keywords: Bulgaria, elections, electoral systems, political parties 